\title{
FORMATION OF PROFESSIONAL COMPETENCIES OF PRIMARY SCHOOL TEACHERS USING ICT
} FORMAÇÃO DE COMPETÊNCIAS PROFISSIONAIS DE PROFESSORES PRIMÁRIOS USANDO ICT FORMACIÓN DE COMPETENCIAS PROFESIONALES DE PROFESORES DE PRIMARIA USANDO LAS TIC

\author{
Sydorenko Natalia ${ }^{1}$ \\ Borisenko Nataliia ${ }^{2}$ \\ Denysenko Veronika ${ }^{3}$ \\ Hrytsenko Iryna ${ }^{4}$
}

\begin{abstract}
The purpose of the publication is to publish the results of a study that reveals how the intensity of the use of ICT in educational activities affects the formation of professional competencies of primary education teachers. With this in mind, the aim of the study is to establish the role of ICT in shaping the online competencies of primary school teachers, to study the content of the competency based approach and the participation of social media platforms and software applications. The object of this study is a complex of ICTs, which actively participates in the formation of competencies of teachers of primary education. The implementation of the objectives of the study requires a set of methods and theoretical analysis and synthesis, as well as methods of comparison, grouping and specification (determination of the research data on the formation of professional competencies of primary school teachers). The results of the research were obtained through the use of qualitative studies (standard focus groups) with subsequent analysis and report preparation. The results of the analysis are used to determine the content and interaction of key and professional competencies in the field of primary education and the high level of use of ICT tools. Almost $80 \%$ of students aged from 20 to 24 used the use of Twitter, Telegram, Facebook in remote education during the academic year 2019/2020.The presented work concludes that the use of ICT, like social media platforms, software applications, software and messenger clouds, increases the level of online competence of teachers and expands the range of professional competencies. The constant modernization of educational content
\end{abstract}

\footnotetext{
${ }^{1}$ Kherson State University. Kherson, Ukraine.

2 Kherson State University. Kherson, Ukraine.

${ }^{3}$ Kherson State University. Kherson, Ukraine.

${ }^{4}$ Kherson State University. Kherson, Ukraine.
} 
based on Twitter, Telegram, Facebook, etc. should be promising for the formation of key and professional competencies and strengthening motivation in the training of primary education teachers.

Keywords: Online competencies, educational platforms, motivation, knowledge acquisition, distance education, knowledge production.

Resumo: O objetivo da publicação é divulgar os resultados de um estudo que revela como a intensidade da utilização das TIC nas atividades educativas afeta a formação das competências profissionais dos professores do ensino básico. Com isso em mente, o objetivo do estudo é estabelecer o papel das TIC na formação das competências online dos professores do ensino básico, para estudar o conteúdo da abordagem baseada nas competências e a participação das plataformas de redes sociais e aplicações de software. $O$ objeto deste estudo é um complexo de TICs, que participa ativamente na formação de competências dos professores do ensino fundamental. A concretização dos objetivos do estudo requer um conjunto de métodos e análises teóricas e síntese, bem como métodos de comparação, agrupamento e especificação (determinação dos dados da investigação sobre a formação de competências profissionais dos professores do ensino básico). Os resultados da pesquisa foram obtidos por meio da utilização de estudos qualitativos (grupos de foco padrão) com posterior análise e elaboração de relatórios. Os resultados da análise são usados para determinar o conteúdo e a interação das competências essenciais e profissionais no campo da educação primária e o alto nível de uso de ferramentas de TIC. Quase $80 \%$ dos alunos de 20 a 24 anos utilizaram Twitter, Telegram, Facebook na educação à distância durante o ano letivo de 2019/2020. O trabalho apresentado conclui que o uso das TIC, como plataformas de redes sociais, aplicações de software, software e mensageiro nuvens, aumenta o nível de competência online dos professores e expande o leque de competências profissionais. A constante modernização dos conteúdos educacionais baseados no Twitter, Telegram, Facebook, etc. deve ser promissora para a formação de competências essenciais e profissionais e fortalecimento da motivação no formação de professores do ensino básico.

Palabras-chave: competências online, plataformas educacionais, motivação, aquisição de conhecimento, educação a distância, produção de conhecimento.

Resumen: El propósito de la publicación es dar a conocer los resultados de un estudio que revela cómo la intensidad del uso de las TIC en las actividades educativas incide en la formación de competencias profesionales de los docentes de Educación Primaria, teniendo en cuenta que el objetivo del estudio es establecer el papel de las TIC en la configuración de las competencias en línea de los maestros de escuela primaria, para estudiar el contenido del enfoque basado en competencias y la participación de plataformas de redes sociales y aplicaciones de software. El objeto de este estudio es un complejo de TIC, que participa activamente en la formación de competencias de los docentes de educación primaria.La implementación de los objetivos del estudio requiere de un conjunto de métodos y análisis y síntesis teóricos, así como métodos de comparación., agrupación y especificación (determinación de los datos de investigación sobre la formación de competencias profesionales de los docentes de primaria). Los resultados de la investigación se obtuvieron mediante el uso de estudios cualitativos (grupos focales estándar) con posterior análisis y elaboración de informes, los resultados del análisis se utilizan para determinar el contenido y la interacción de competencias clave y profesionales en el ámbito de la educación primaria y el alto nivel de uso de herramientas TIC. Casi el $80 \%$ de los estudiantes de 20 a 24 años utilizaron Twitter, Telegram, Facebook en educación remota durante el año académico 2019/2020. El trabajo presentado concluye que el uso de las TIC, como plataformas de redes sociales, aplicaciones de software, software y mensajería nubes, aumenta el nivel de competencia online de los docentes y amplía el abanico de competencias profesionales La constante modernización de los contenidos educativos basados en Twitter, Telegram, Facebook, etc. debe ser prometedora para la formación de competencias clave y profesionales y el fortalecimiento de la motivación en la formación de profesores de educación primaria.

Palavras chave: Competencias online, plataformas educativas, motivación, adquisición de conocimientos, educación a distancia, producción de conocimientos. 


\section{INTRODUCTION}

In modern education, social and media platforms as a space for the formation of online competencies are mandatory. The use of ICT, namely such social platforms as Facebook, is of great importance for teachers, specialists and the future specialists of primary education. Such social networks in conditions of priority of distance learning give an opportunity not only to teach profile subjects but also motivate to improve communication and speech skills, give an opportunity to express their own opinion, produce an individual style of teaching and create a new educational product.

It is very important to teach the student to express their own opinion on current issues and their own problems. ICTs provide such an opportunity: to place educational materials, make them publicly available, and motivate them in a simple way (Bilal, Ghayyur, Kanwal, Nazir, Ruba, 2019; Mykytiuk, Lysytska and Melnikova, 2020). That is why the analysis of the effectiveness, accessibility and attitude of primary education teachers to social media platforms and groups in the educational message clouds, i.e., the analysis of attitudes and the level of information and methodological support with the involvement of ICT is one of the main topics for modern research in the field of teaching methods (Giachanou and Crestani, 2016); Popovych, Ragimov, Kornienko, Ivanova, Buryk, (2020), pedagogy (Gorard, See and Davies, 2012), computer science (Giachanou and Crestani, 2016; Tashakori and Haghighat, 2019; Tawafak, Romli, Arshah and Almaroof, 2018). This determines the relevance of this research problem and the proposed study.

The possibilities of educational platforms and ICT in the conditions of intensification of distance education are insufficiently researched. It is also important to analyze the extent to which the knowledge gained and produced based on social media networks is crucial for the algorithm of the formation of professional and online competencies.

First, Twitter should be analyzed as a system of microblogging and social networking platforms, where different forms and types of texts are promptly published every day, and therefore must be effective in developing knowledge and competencies. Note that tweets are limited to 140 characters.

Secondly, it is planned to explore the educational potential of Facebook platforms and cloud messenger Telegram, where you can create thematic groups and instantly publish the necessary materials: graphics, video, audio, or verbal messages. Besides, how important is the fact that each social media platform also uses a set of keys and hashtags, which facilitate the search, identification and processing of the information provided. This facilitates the search for the necessary materials and helps to spread a wider audience to the topic under discussion. A cloud messenger is software for technical communication devices and PCs, so let's consider its communication potential and capacity, taking into account the possibility of feedback.

Third, the study analyzes the extent to which ICT systems make it possible to determine the quality, effectiveness and nature of the use of educational materials presented on social media platforms. The priority of ICT for the analysis of the effectiveness of various educational applications and groups is determined. The latter can be an effective tool for forming the whole complex of competencies and motivation of primary education teachers.

The analysis of the role and effectiveness of social media platforms, applications to them and messenger channels in terms of activating distance education provided consideration of motivation, informational and methodological value of texts and educational materials created and distributed with the participation of such platforms. It is also taken into account that ICT in the modern pedagogical space is also a business activity of education (Coe, 2017).

The study aims to review and analyze the stages and forms of existing approaches to the use of social platforms such as Facebook and cloud messengers (TELEGRAM) in order to develop professional competencies and motivation of primary education teachers. It is necessary to determine the degree of 
effectiveness and the prevalence of the use of ICT in distance education, which contributes to the formation of the evolution of the professional competencies of primary school teachers.

The leading research task of this publication is to analyze the effectiveness of ICT in the formation of professional competencies of primary school teachers, as well as to determine the prospects for the development of educational platforms based on social platforms, messengers and their software applications. Accordingly, the article provides a section containing information about the base and functional role of ICT in the study; a section that provides a brief description of stages of approaches to the formation of competencies of elementary school teachers by ICT, also provides an overview of classifications, and the results of educational portals, groups, blogs, etc. and their evaluation directly by primary school teachers for the period 2019/2020. In the work of designing professional competencies should be classified and presented an applied algorithm of formation (4 stages). It is also important to describe the size and quality of the data complex, the channels of their use, which are presented in the analysis and the results.

\section{LITERATURE REVIEW}

In this part we will consider a number of works that contain classifications and stages of formation of professional competencies with the involvement of ICT. We will also describe the field of experiments and their results, which were carried out with the involvement of social networks, software applications, messengers during training.

A number of successful investigations were conducted (Mykytyuk, Lysytska and Melnykova, 2020) on the possibility of using social platforms, social networks, groups, messengers Sim and Pop (2014) etc. be primary school teachers in the competent education unit, the essence and algorithm of professional competencies are clarified (Hutorskoj, 2005), the means of ICT in the educational space of teacher training that promote the study of foreign languages by means of ICT are identified (Ahmad, 2016), the potential of social communications in the formation of online competence and student motivation is analyzed (Kuzmina, Protas, Fartushok, Raievska, Ivanova, 2020; Mason, 2006). It is also a study about the use of Facebook opportunities in learning foreign languages (Kostikova, Miasoiedova, Razumenko, Chernenko and Pochuieva, 2019). Researches of formation process of professional competences through inoculation of information culture to students of humanitarian specialties were carried out (Synorub and Medynska, 2019).

We have a sufficient number of articles with the analysis of the quality and effectiveness of social networks in the formation of competencies of teachers and educators in various fields, where the emphasis is on the creative basis of this training (Lisichko, Postnikova and Tverdokhlebov, 2012). As well as many current studies are about changes in the nature of approaches to the formation of a set of key competencies and their correlations with the professional competencies of educators (Hutorskoj, 2005). It is important that the discussion is about the relationship between leadership and the ability to use pedagogical tools (Ko, Sammons and Bakkum 2013), motivation to acquire knowledge and ICT opportunities (Bramschreiber, 2012).

The researchers have recently focused their attention on the educational potential of communication and media platforms (Kuzmin, Kuzmina and Ivanchenko, 2017). A lot of attention is paid to the study of public educational platforms in the Internet space and presents such projects as successful ones. These projects form the professional competencies of top specialists in the education sphere (Ivanova, 2020).

Directions of study focus on linguistic and didactic (Shim and Lee, 2018), analysis of philosophical, methodological and psychological foundations (Howard-Jones, 2014), efficiency and business feasibility of materials (Kuzmin, Kuzmina and Ivanchenko, 2017), the role of software in the formation complex of educational competencies (Khutorskaya, 2005). Machine learning is studied as a way to improve information and communication skills (Sim and Pop, (2014), hybrid forms of learning (lexicon-approaches, graphapproaches, involvement of quiz-methods, etc.) (Malik, 2016). 


\section{AIMS}

The purpose of the study, which is the subject of this article, is to review and analyze the stages and forms of existing approaches to the usage of social platforms, such as Facebook, cloud messengers (TELEGRAM) in order to form professional competencies of primary school teachers.

It is necessary to determine the degree of effectiveness and the prevalence of the usage of ICT in distance education, which contributes to the formation of the evolution of professional competencies of primary school teachers.

In the work the applied algorithm of formation (4 stages) is classified and the prose of creation of professional competencies is presented. It is also important to describe the size and quality of the data set, the channels of their use which are presented in the analysis and the results.

The analysis of efficiency of application of ICT and definition of prospects of development of educational platforms on the basis of social platforms, messengers and their software applications is provided. The rest of the article is organized in this way: Part 4 contains information concerning the basis and functional role of ICT in the study; Part 5 provides a brief description of the stages of approaches to the formation of competencies in primary education teachers through ICT, also provides an overview of classifications and results of educational portals, groups, blogs, etc. and their evaluation directly by primary school teachers for 2019/2020. Part 6 contains a review and analysis of the study results.

\section{METHODS}

The section presents a set of methods that are necessary in the study of competency education and the role of ICT. The article uses research materials created using a research approach, as well as an overview of research on this topic and factual materials, statistics presented on the sites and in the analytical data of Alexa, Facebook Reports, Kantar TNS. The considered activity, materials and statistics are limited to the European institutions that took an active part in the training of primary education teachers for the period 2019/2020.

The obtained materials were selected according to a number of criteria.

1. Materials are presented in the social network Internet.

2. Training courses that use communication opportunities. The main parameters are Twitter, Telegram, Facebook.

3. Works containing data with quantitative approaches, statistical results.

4. Materials that determine the facts and situations of using ICT to increase the level of competence of primary school teachers.

In order to achieve research goals, the following methods are used in the work:

- method of theoretical analysis and synthesis for the study of theoretical foundations in determining the correlations of key and basic competencies;

- methods of comparison, grouping, classification and specification in order to assess the results of the use of ICT;

- stage method is used to distribute the stages of formation of professional competencies.

In order to obtain the results, a qualitative research method and analysis of the results of the survey of standard focus groups (7 people each) were used. In total, 3 groups ( 24 students) took part in the survey. 
2 groups are basic groups and 1 is the control group. Participants were offered a number of open-ended questions with preliminary explanations of the purpose of the questions.

The results were obtained and presented with the help of student groups aged 20 to 24 , the basis for the study was a number of European universities (Zaporizhzhya National University, University of Latvia, Ternopil Volodymyr Hnatiuk National Pedagogical University), public educational platforms, analytical agency BezBrehni, Cem the Center for evaluation and monitoring, Cambridge family), which train primary school teachers or participate in the training of specialists in this field.

\section{RESULTS}

The formation of professional competencies depends on the quality and availability of educational content, among which social platforms, communication services, software, applications, etc. play an important role in the modern technological revolution. Twitter, Telegram, Facebook are effective means of ICT in the formation of competencies of primary school teachers. Facebook and Telegram are designed to partially solve the problem of the formation and evolution of professional competencies of primary education teachers, allow to analyze its quality and efficiency even from the point of view of educators and teachers, taking into account their opinions and attitudes. However, such research is a difficult task because of the huge amount of materials (tweets, interest groups, blogs, etc.) available. The research group (Hamre, Goffin and Kraft-Sayre, 2009) calls for research in this area to develop new approaches that can increase the effectiveness of ICT, namely to identify the most effective and positively evaluated methodological and educational developments among the huge amount of data. Distance education is provided on the main platforms, and primary school teachers are no exception.

The competence approach is closely linked to the channels of obtaining new educational information in modern pedagogy. ICT promotes the activation of cognitive activity of the student, promotes the formation of creative skills and this is especially important in the world of primary school teachers. Distance learning in the $2019 / 2020$ academic year has contributed to the transformation of the system of key and professional educational competencies.

This transition is related to the technical support of universities, students, technological capabilities in the country as a whole. ICT Involvement gives the teacher the opportunity to independently obtain information, transform it, as well to have an idea about the quality of knowledge on the basis of the test results and effectiveness of the used learning platforms.

The formation of professional competencies becomes more widespread and diverse when the potential of Internet resources and software of communication channels is used in the learning process. It also allows expanding the set of methods of pedagogical and psychological influence. The readiness of a primary school teacher for more effective activities is determined by a set of professional competencies, where the ability to conduct project activities, communicative and information-digital aspects of competence come to the fore.

In addition, the formation of a complex of competencies is also activated by interactive teaching methods, which are possible in the field of media and social platforms and form a willingness to continue professional activities and career growth.

ICT is used to introduce multi-level monitoring of the algorithm for the formation of professional competencies in primary school teachers. It is the first aspect. The second aspect is the components of professional work in the sphere of Twitter, Telegram and Facebook. They are worked out in order to learn to form project tasks in the competence approach. 
Competence approach is carried out during educational activities (lectures, workshops, practical, game classes, etc.), which are performed under the influence of IT technologies and with their direct assistance. It is also necessary to take into account the availability of technical base and psychological readiness of all participants in the educational process to such forms of work (teachers, students, universities, technical staff, etc.).

\section{Classification of educational competencies}

The key educational competencies (Hutorskoj, 2005) that should be formed by specialists in primary school with the help of ICT are the following:

1) value and semantic competence is associated with the presence of a formed worldview and the ability to form the values of the student, to be able to choose the target and value settings. Be aware of your professional responsibilities, have creative way of thinking, be able to make decisions. This is an opportunity for self-determination in the profession and society. The algorithm of vital activity depends on this competence.

2) General cultural competence forms the level of awareness in the guidelines of general culture, moral guidelines, cultural and social rules of behaving. This competence implies the presence of curiosity. The level of professional awareness of the teacher, his/her skill as a practice, extensive experience is important. For example, it is about the ability to organize effectively their leisure and the leisure time of students and parents.

3). Learning and cognitive competence is interpreted as the ability to carry out independent cognitive activity (goal setting, planning, creation of ideas, analytical and reflective skills, self-assessment skills of their own work). This competence also includes a very important feature for the teacher - creativity, the ability to make decisions in unusual situations (Gorard, See, Davies, 2012). Skills in media literacy, the ability to distinguish truth, half-truth, manipulation of facts and ability to use statistics are becoming a modern requirement.

4). Information competence consists of the ability to use real tools (video, audio systems, faxes, copying machines and other technical means in education) and ICT to obtain information, its analysis, evaluation and usage. In our opinion, this competence should be given the ability to use online platforms as a means of learning during distance education.

5). Communicative competence presupposes, first of all, a high level of proficiency in the language of instruction, as well as proficiency in foreign languages. In a situation where bilinguals predominate in the country (part of Eastern Europe, post-Soviet countries), a high level of communicative competence helps to learn other foreign languages very easily. The teacher must have document management skills, rhetorical skills and blogger skills. To improve this competence, ICT tools allow you to choose and record a number of ways to present educational material and forms of work with it.

6). Social and labor competence involves the improvement and evolution of the level of involvement in the public space (to have a public, representative, electoral position), the field of professional selfdetermination and improvement. This is the ability to determine the necessary areas in a large body of educational and methodological material.

7). Competence of personal self-improvement. This is, first of all, a constant desire of professional and personal self-improvement and self-education. The teacher is constantly mastering new activities, developing the necessary technology, knowledge and skills for professional growth, developing as a person and a professional. 
Figure 1. Key educational competencies

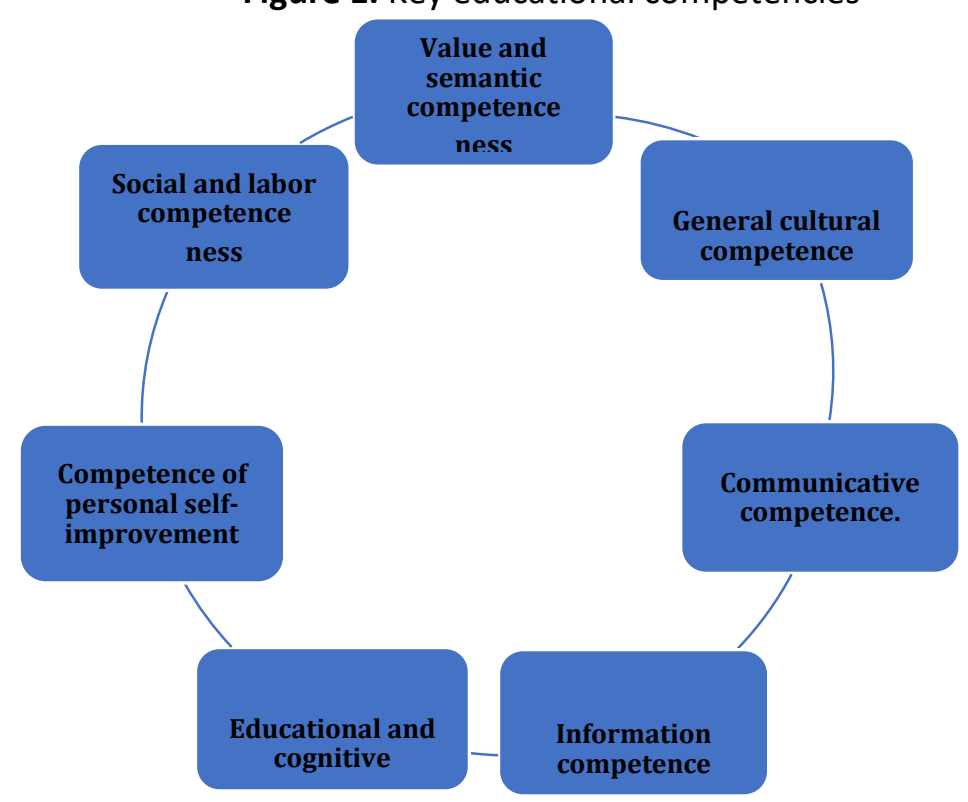

Key competencies are correlated with more specific - professional ones. Professional competencies should also be presented in a complex.

\section{Stages of creating professional competencies}

Education will provide a holistic competency education of primary school teachers being created on the basis of professional and key competencies. Educational professional competencies play a multifunctional meta-subject role, which, as we see not only a professional but also a socio-cultural one.

Professional competencies can be represented as follows.

1. Those that allow the usage of modern educational content, new technologies and methods: Linguistic and communicative competence, subject competence, information and digital competence

2. Professional competencies that implement interaction with participants in the educational process: Psychological competence Emotional and ethical competence Competence of pedagogical partnership

3. Competences responsible for the ability to organize a healthy, developmental, inclusive educational environment (inclusive competence, health-preserving competence, design competence).

4. Those that allow managing the educational process (prognostic competence, evaluation-analytical competence, organizational competence.

5. Innovative competence, ability to learn lifelong, reflexive competence are connected with continuous professional development.

The construction of professional educational competencies is based on the reflexive identification of the competency content of education and it can be conditionally algorithmized in four stages: 
Scheme 2. Stages of formation of professional competencies in the educational space.

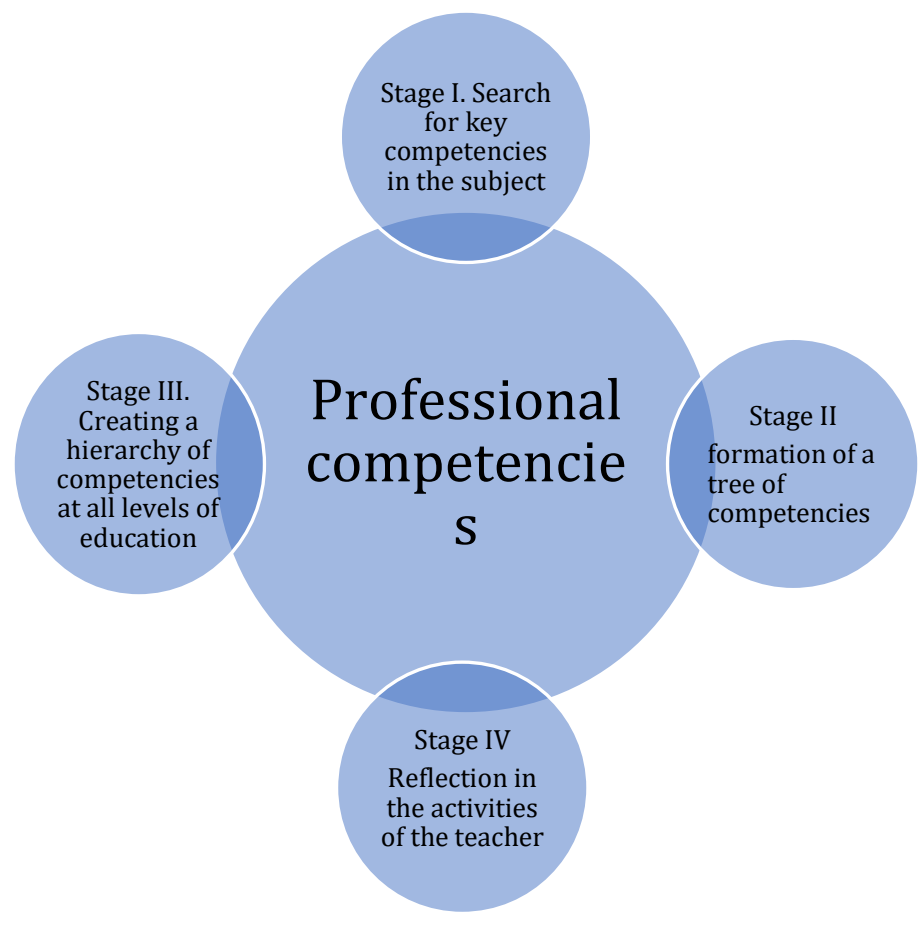

1) search for manifestations of key competencies in each specific subject;

2) construction of hierarchical supra-subject systematics - "tree of competencies";

3) designing general subject educational competencies at the vertical level for all three levels of education;

4) projection of competencies formed by degrees on the level of subjects and their reflection in educational standards, curricula, textbooks and teaching methods.

\section{Basic parameters Twitter, TELEGRAM, Facebook}

Let's consider Twitter as a learning platform through which professional competencies are formed. This micro blogging network was launched in 2006. Twitter allows users to post tweets quickly. These are text messages and with them you can submit the necessary educational content (images, articles, websites, etc.) and get feedback and evaluations from other users of the platform.

Each tweet has a maximum volume of 140 symbols, which can contain an algorithm of actions, a description of methods, training materials, as well as receive reviews, opinions - in general, the reaction of users to the presented product. It is important that all posts can have links to articles on the topic, actual material on the topic, videos, images, etc.

The tweet also uses hash tags that mark the topic under discussion. Statistics provided by Twitter show that there are more than $320 \mathrm{~m}$ of active accounts with $500 \mathrm{~m}$ of tweets sent every day (Giachanou and Crestani, 2016). Below you can see the effectiveness of competency creating using Twitter. 
Table 1. The number of tweets within the educational content (data obtained directly by the research group)

\begin{tabular}{|c|c|c|c|c|}
\hline $\begin{array}{l}\text { Institution, educational } \\
\text { resource }\end{array}$ & Professional competence & $\begin{array}{l}\text { Tweets } \\
2019\end{array}$ & $\begin{array}{l}\text { Tweets } \\
2020\end{array}$ & $\begin{array}{l}\text { Results } \\
\text { (\%) }\end{array}$ \\
\hline EdCamp Ukraine & $\begin{array}{l}\text { Information and digital competence } \\
\text { Ability to learn lifelong } \\
\text { Competence of pedagogical partnership }\end{array}$ & 581 & 1291 & $\begin{array}{l}\text { Increased } \\
122,2\end{array}$ \\
\hline $\begin{array}{l}\text { Cem the Centre for } \\
\text { evaluation and } \\
\text { monitoring, Cambridge } \\
\text { family }\end{array}$ & $\begin{array}{l}\text { Information and digital competence } \\
\text { Ability to learn lifelong } \\
\text { Competence of pedagogical partnership }\end{array}$ & 947 & 1104 & $\begin{array}{l}\text { Increased } \\
16,6\end{array}$ \\
\hline $\begin{array}{l}\text { Latvijas Universitate's } \\
\text { Twitter page }\end{array}$ & $\begin{array}{l}\text { Information and digital competence } \\
\text { Ability to learn lifelong } \\
\text { Competence of pedagogical partnership }\end{array}$ & 12753 & 18970 & $\begin{array}{l}\text { Increased } \\
50,9\end{array}$ \\
\hline $\begin{array}{l}\text { Zaporizhia National } \\
\text { University } \\
\text { Twitter page }\end{array}$ & $\begin{array}{l}\text { Information and digital competence } \\
\text { Ability to learn lifelong } \\
\text { Competence of pedagogical partnership }\end{array}$ & 403 & 1000 & $\begin{array}{l}\text { Increased } \\
148,1\end{array}$ \\
\hline
\end{tabular}

This group includes those institutions that use Twitter as a platform for training and education.

Facebook is the largest social network in the world. It has been working since 2004. From the very beginning, Facebook was intended for students. According to Alexa, the site Facebook.com ranks the 3rd in traffic in the world (Alexa, 2020). In 2017 the number of users was 2 billion people worldwide. [8]

In order to carry out the learning process, Facebook users can organize into interest groups, communicate and exchange information through private or public messages and chats. The educational potential of Facebook should also include the function of blogging (Sim and Pop, 2014). All this allows users to communicate in groups, learn in the mode of the Internet messenger. Public educational platforms in the post-Soviet countries (Ukraine, Latvia) and a number of European countries (Great Britain, Latvia) are popular among primary school teachers and they are actively used in the process of distance education. Public educational platforms influence the formation of professional competencies. It was clearly seen during the 2019/2020 academic year. 
Table 2. The usage of Facebook groups (data obtained directly by the research group)

\begin{tabular}{|l|l|l|l|}
\hline Training resource & Professional competence & Number of & subscribers \\
& & 2019 & Subscribers \\
& & 2020 \\
\hline EdCamp Ukraine & Ability to learn lifelong \\
Competence of pedagogical partnership & 24000 & 26002 \\
\hline $\begin{array}{l}\text { Cem the Centre for } \\
\text { evaluation } \\
\text { monitoring, } \\
\text { Cambridge family }\end{array}$ & $\begin{array}{l}\text { Anformation and digital competence } \\
\text { Ability to learn lifelong }\end{array}$ & 1200 & 1440 \\
\hline $\begin{array}{l}\text { Analytical agency } \\
\text { BezBrehni } \\
5420\end{array}$ & $\begin{array}{l}\text { Information and digital competence } \\
\text { Ability to learn lifelong } \\
\text { Competence of pedagogical partnership }\end{array}$ & 1350 & 5420 \\
\hline
\end{tabular}

It should be noted that open learning platforms are easier to analyze in terms of their usage as training platforms for the formation of professional competencies. Multi-vector and a large number of educational programs in university education do not provide such an opportunity to clearly outline such opportunities of Facebook pages in university communities, which are aimed at the formation of professional competencies of primary school teachers.

Telegram cloud messenger, software for smartphones, tablets and PCs is widely used to organize distance learning groups during a pandemic period. This messenger makes it possible to exchange text messages, graphics and video files, as well as make it possible to call users of the program. The practice of creating study groups intensified during distance learning. This has in some ways changed the learning process and transformed the set of professional competencies. A survey of students and teachers on the feasibility of using messenger, telegrams, Facebook was conducted on the basis of several European universities.

In the columns students identified a set of social platforms and software used in the process of forming professional competencies. The group consisted of 24 students from European universities aged 20 to 24 , studying in the department of "primary education teacher". The number of respondents was determined by the number of students in the groups and the size and number of standard focus groups involved in the study. There are 3 focus groups of 7 people. 2 groups are basic groups and 1 group is the control group. A number of relevant questions were open ended, preceded by a detailed discussion by the moderator of what and how to establish as a result of the conversation. These are 2 blocks of questions. Block 1 was devoted to those information and media platforms, software and social networks that contribute to the formation of online competence in the context of distance education, and the problem of accessibility of the Internet resource was also considered. Block 2 of the questions was devoted to priority competencies in the field of ICT impact. 
Table 3. The usage of ICT (data obtained directly by the research group)

\begin{tabular}{|l|l|l|l|}
\hline Institution & Use of Twitter, & Use of TELEGRAM, & Use of Facebook \\
\hline Latvijas Universitate's & $67 \%$ & $80 \%$ & $76 \%$ \\
\hline Zaporizhia National University & $54 \%$ & $76 \%$ & $68 \%$ \\
\hline $\begin{array}{l}\text { Ternopil Volodymyr Hnatiuk } \\
\text { National Pedagogical University }\end{array}$ & $60 \%$ & $78 \%$ & $63 \%$ \\
\hline
\end{tabular}

Some students (20\%) who studied at Ukrainian universities noted that they were not able to use ICT opportunities because there was no Internet in their localities. This explains the lack of a high result.

A group of students was interviewed about the content of competencies, which in their opinion were formed by involving media and social networks and software in the educational process. The question was presented as follows:

"What competencies were formed with the help of social networks and software?"

There was a task to choose from the list of presented competencies those that are formed through training on media platforms and software Twitter, Telegram, Facebook.

From the proposed 7 professional competencies, it was necessary to choose 3 that are most formed due to the involvement of ICT. The majority of respondents ( $83 \%$ of respondents) identified three main professional competencies: information and digital competence, competence of pedagogical partnership, ability to learn throughout life.

Table 4. Self-assessment by a group of priorities in the formation of professional competencies through ICT (data obtained directly by the research group)

\begin{tabular}{|l|l|l|l|}
\hline Institution & $\begin{array}{l}\text { Information and digital } \\
\text { competence }\end{array}$ & $\begin{array}{l}\text { Competence of } \\
\text { pedagogical partnership }\end{array}$ & Ability to learn lifelong \\
\hline $\begin{array}{l}\text { Latvijas Universitate's } \\
\text { Zaporizhia National } \\
\text { University }\end{array}$ & $74 \%$ & $60 \%$ & $78 \%$ \\
\hline $\begin{array}{c}\text { Ternopil Volodymyr } \\
\text { Hnatiuk National } \\
\text { Pedagogical University }\end{array}$ & $79 \%$ & $75 \%$ & $83 \%$ \\
\hline
\end{tabular}

The second block of surveys concerned the shortcomings and positive aspects of using Twitter, Telegram, Facebook for educational purposes. Question 1 was an open type: Say the shortcomings and 
difficulties in working with media and social platforms and their software. Question 2 was an open type: Say the main preferences that contribute to the professional and competence development of students.

Students noted positive features of Telegram and said the following:

- Ability to archive chats in the thematic section.

- Archived chat can be opened via a special notification.

- Due to the messenger you can conduct surveys.

- Text messages can be chanced and all types of message can be attached.

Telegram has a number of shortcomings that were noted in the group:

- Insufficient software (video calls cannot be made) and it is inconvenient to conduct presentation and educational and game activities,

- Does not have a sufficient level of confidentiality, also requires certain technical conditions and equipment for all participants in the process.

The advantages of Facebook are:

- Opportunity to organize groups, join them.

- Availability of own settings.

- Ability to blog (Facebook-notes)

- Availability of feedback.

Facebook difficulties:

- The need for technical equipment, the availability of network coverage,

- Difficult to perceive and frequently changed interface,

- Ads.

Twitter is characterized by a number of positive features:

- Ability to produce texts,

- Possibility of feedback

- Works with the availability of technical equipment for all members of the group, requires software, Internet connection.

\section{DISCUSSION}

The analyzed research context shows that the use of a rich arsenal of ICT is an area open to research. Innovative approaches to the formation of professional competencies have always been relevant, and especially such a need arose in 2019/2020 with the actualization of distance education. In fact, online education actively uses the blogging function and improves the ability to make decisions in non-standard situations (Gorard, See, Davies, 2012; Sim and Pop, 2014; Ivanova, Mosenkis, Strokal, 2020), allows to increase the level of communicative competence through Twitter posts (Giachanou and Crestani, 2016), so social networks and their software can be used as an educational platform and be a tool for the formation of professional competencies. Increasing the involvement of primary school teachers in the training of online 
educational products and opportunities for social networks and social platforms in distance education is a productive and promising direction in all forms of European education from non-formal educational platforms to traditional classical and universities (Martín-Gutiérrez, Efrén Mora, Añorbe-Díaz, GonzálezMarrero, 2017).

The modern process of formation of professional competencies should combine the traditional form of learning (direct communication) and learning through social electronic networks, learning platforms. People now can use a wide range of software applications. And all this is in a close combination of theory, modern technology and cognitive sciences. Pedagogical science should use social networks, educational platforms, which are part of the modern educational space as a platform for the formation of educational competencies.

Undoubtedly, as research in this field (Boaler, 2008) shows, large amounts of information at such sites complicate research work. But there is the positive dynamics in conducting research concerning the quality of learning and competency-based approach to learning. The usage of ICT contributes to form a set of necessary professional competencies of the teacher in his/her further activities.

\section{CONCLUSION}

As it is noted in research (Giachanou and Crestani, 2016) and in order to support our findings, there is a growing demand for advanced technologies that can be effectively applied in the educational environment. The research group came to the conclusion that there is a growing demand for such ICTs, which provide quality distance learning and professional self-improvement. And social networks, message clouds also have constant feedback between all participants in the process of formation and improvement of professional competencies. This allows you to easily and timely adjust the education process. In this regard, both in our study and in others, there is an increase in the number of users of educational platforms, educational groups on social networks. Accordingly, this requires advanced technologies and methodologies. That is why the new approaches to the formation of professional competencies are increasingly using the capabilities of Twitter, Telegram, Facebook, Facebook (Sim and. Pop, 2014).

Compared to 2019, the usage of Twitter at Ternopil Volodymyr Hnatiuk National Pedagogical University increased by $148 \%$; Latvijas Universitate's Twitter page at 50.9\%; Cem the Center for evaluation and monitoring at $16.6 \%$; EdCamp Ukraine at $122.2 \%$. This is due to the increase of distance education associated with quarantine measures.

We believe that such approach is necessary for modern education, which is becoming more and more distant. The special conditions of the modern educational process are dictated by the fact that we are in the space of large flows of information and the presence of a significant number of social networks, software and applications that can operate in real time.

Educational content that serves to form professional competencies can be used on the basis of social media platforms to create effective methods of teacher competence growth. In addition, such platforms can be used by professionals to continuously and lifelong mastering of their professional level and level of competence. We believe that in the near future research should focus on the use of the full potential of ICT in the educational activities of primary school teachers. 


\section{REFERENCES}

Ahmad, M., (2016) Using Facebook to develop grammar discussion and writing skills in English as a foreign language for university students. Sino-us English Teaching, 8(12), 932-952.doi.org/10.17265/15398072/2016.12.004.

Alexa. The top 500 sites on the web. 2020. Retrieved from URL https://www.alexa.com/topsites

Amrein-Beardsley, A. (2008) Methodological concerns about the education value-added assessment system. Educational Researcher, 37(2), 65-75.doi.org/10.3102/0013189X08316420

Askew, M., Brown, M., Rhodes, V., Wiliam, D., \& Johnson, D., 1997. Effective Teachers of Numeracy: Report of a study carried out for the Teacher Training Agency. London: King's College, University of London. Retrieved from URL https://nrich.maths.org/content/id/10757/EffectiveTeachersofNumeracy.pdf

Boaler, J. (2008) When politics took the place of inquiry: A response to the National Mathematics Advisory Panel's review of instructional practices. Educational Researcher, 37(9), 588-594. doi: 10.3102/0013189x08327998

Boa Sorte, P. (2020). Mark the correct answer? To whom? Deconstructing reading comprehension. Journal of Research and Knowledge Spreading, 1(1), 1-8.

Bramschreiber, T., (2012) Taking Peer Feedback to Heart. Educational Leadership, 70(3). Retrieved from URL http://www.ascd.org/publications/educationalleadership/nov12/vol70/num03/Taking-PeerFeedback-to-Heart.aspx

Coe R. 6 elements of great teaching. 2017. Retrieved from URL http://www.cem.org/blog/6-elements-ofgreat-teaching

Ebrahimi, M. A. (2020). Cultural value of translation of proverbs and synopsis. Journal of Research and Knowledge Spreading, 1(1), 1-10.

Fullagar, S. (2019). A physical cultural studies perspective on physical (in)activity and health inequalities: the biopolitics of body practices and embodied movement. Revista Tempos e Espaços em Educação, 12(28), 63-76.

Giachanou A. and Crestani F., 2016. Like It or Not: A Survey of Twitter Sentiment Analysis Methods, ACM Comput. Surv., vol. 49, no. 28, 35-49. doi.org/10.1145/2938640

Gorard, S., See, B. H., Davies, P. (2012). The impact of attitudes and aspirations on educational attainment and participation. York: Joseph Rowntree Foundation. Available at: http://www.jrf.org.uk/sites/files/jrf/education-young-people-parents-full.pdf.

Hamre, B.K., Goffin, S.G., Kraft-Sayre, M. (2009) Classroom Assessment Scoring System Implementation Guide: Measuring and Improving Classroom Interactions in Early Classroom Settings. Retrieved from URL http://www.teachstone.org/wpcontent/uploads/2010/06/CLASSImplementation

Howard-Jones, P.A. (2014) Neuroscience and education: myths and messages. Nature Reviews Neuroscience. Advanced Online Publication, 1-7. doi:10.1038/nrn3817.

Hutorskoj A. V. 2005. Tekhnologiya proektirovaniya klyuchevyh i predmetnyh kompetencij. Retrieved from URL http://www.eidos.ru/journal/2005/1212.htm

Kuzmina, M. O., Protas, O. L., Fartushok, T. V., Raievska, Y. M. Ivanova, I. B. (2020) Formation of Students' Competence of Tertiary Educational Institutions by Practical Training Aids International Journal of Higher Education Vol. 9, no. 7, 279-288. doi:10.5430/ijhe.v9n7p279 
Ivanova I.B. (2020) Media project "Nakipillo" as a successful experience in the development of independent media Actual problems of media space: materials of the SECOND All-Ukrainian Scientific and Practical Conference (Kyiv, April 09, 2020), pp. 207-210. Retrieved from URL: http://journ.knu.ua/nauka1/090420-2 (in Ukrainian).

Ko J., Sammons P., Bakkum, L. (2013) Effective Teaching: a review of research and evidence. CfBT Education Trust. $\quad$ Retrieved from URL http://cdn.cfbt.com/ /media/cfbtcorporate/files/research/2013/reffective-teaching-2013.pdf

Kostikova, I., Miasoiedova, S., Razumenko, T., Chernenko, A., \& Pochuieva, O. (2019). Teaching English speaking for FCE: Using Facebook as a tool of instructional practice. Amazonia Investiga, 8(22), 719727. https://amazoniainvestiga.info/index.php/amazonia/article/view/825/773

Kuzmin, V., Kuzmina, M., Ivanchenko, A. Psychosocial life trajectories of orphaned individuals (resurvey) // Science and Education. 2017, no. 10, 95-100. doi.org/10.24195/2414-4665-2017-10-12.

Lisichko, E., Postnikova, E., \& Tverdokhlebov, S. (2012). Formation of professional competence of students in engineering education. Creative Education, 3(7), 104-106. https://doi.org/10.4236/ce.2012.37B027

Malik S.I. (2016) Enhancing practice and achievement in introductory programming using an ADRI editor, In Proceedings of the IEEE International Conference on Teaching, Assessment and Learning for Engineering, 32-39, IEEE, Thailand, 7-9 December. doi.org/10.1109/tale.2016.7851766

Mykytiuk S., Lysytska O., Melnikova T. (2020) Facebook Group as an Educational Platform for Foreign Language Acquisition Postmodern Openings 2020, Volume 11, Issue 1 Supl. 1, 131-157. doi.org/10.18662/po/11.1sup1/127

Santos, I. T. R., Barreto, D. A. B., \& Soares, C. V. C. O. (2020). Formative assessment in the classroom: the dialogue between teachers and students. Journal of Research and Knowledge Spreading, 1(1), 1-14.

Shim, H., \& Lee, S. (2018). Development of educational materials using Prezi as digital storytelling tool. Journal of Theoretical and Alied Information Technology, 96 (22), 7491-7499. http://www.jatit.org/volumes/Vol96No22/17Vol96No22.pdf

Sim, M., \& Pop, A. (2014). The impact of social media on vocabulary learning: Case study Facebook. Annals of the University of Oradea. Economic Science Series, 23(2), 120-130. https://ideas.repec.org/a/ora/journl/v2y2014i2p120-130.html

Synorub H., Medynska O. (2019) Development of information culture of students of humanitarian specialities. Information Technologies and Learning Tools. 2019, Vol 72, no. 4, 152-167. doi.org/10.33407/itlt.v72i4.2922

Tashakori, S., Haghighat, S. (2019). Designing the intelligent system detecting a sense of wonder in english speech signal using fuzzy-nervous inferenceadaptive system (ANFIS). BRAIN. Broad Research in Artificial Intelligence and Neuroscience, no 10(1), 55-63. Retrieved from URL https://pdfs.semanticscholar.org/5c91/68e029024642f76d362bb396e176d793e9fd.pdf

Tawafak R.M., Romli A.B., Arshah R.B.A., Almaroof R.A.S, (2018) Assessing the Impact of Technology Learning and Assessment Method on Academic Performance: Review paper, Eurasia Journal of Mathematics, Science and Technology Education, Vol. 14, no. 6, 22412254.doi.org/10.29333/ejmste/87117. 


\section{ABOUT THE AUTHORS}

\section{Sydorenko Natalia}

Candidate of Philological Sciences, Associate Professor, Pedagogical faculty, Department of Theory and Methods of Preschool and Primary Education. Kherson State University. Kherson, Ukraine.

E-mail: n3anna3n@gmail.com

ORCID: https://orcid.org/0000-0003-2050-4938

\section{Borisenko Nataliia}

PhD in Education, Candidate of Pedagogical Sciences, Associate Professor, Pedagogical faculty, Department of Theory and Methods of Preschool and Primary Education. Kherson State University. Kherson, Ukraine.

E-mail: svitlana.mkal@gmail.com

ORCID: https://orcid.org/0000-0003-3515-4766

\section{Denysenko Veronika}

Candidate of Pedagogical Sciences, Associate Professor, Pedagogical Faculty, Department of Pedagogy and Psychology Preschool and Primary Education. Kherson State University. Kherson, Ukraine.

E-mail: wiolettawwwww@gmail.com

ORCID: https://orcid.org/0000-0002-5461-6914

\section{Hrytsenko Iryna}

Candidate of Pedagogical Sciences, Associate professor, Pedagogical Faculty, Department of Pedagogy and Psychology Preschool and Primary Education. Kherson State University. Kherson, Ukraine.

E-mail: dencicov@yandex.ru

ORCID: https://orcid.org/0000-0002-1293-8261 